\title{
Sustainable development and tolerance in the socializing and resocializing of the architectural environment of cities
}

\author{
Nadiia Shebek*, Viktor Timokhin, Yuliia Tretiak, Ievgenii Kolmakov, and Oleksandr Olkhovets \\ Kyiv National University of Construction and Architecture, 31 Povitroflotskyi Ave., Kyiv, 03680, Ukraine
}

\begin{abstract}
The article considers the sustainable development of the city public spaces and the penitentiary complexes problems from the Synergetics and Socionics standpoint. These approaches provide consideration of the opposite processes of public spaces socialization and correctional complexes resocialization, sustainability, and dynamism its organization, and self-organization. The regularities of sustainable development are present in the cyclical nature of historical changes in public spaces and the penitentiary system. Cycles unfold in the alternation order of pairwise polarized processes, on the one hand, dispersion and concentration, and, on the other, - self-organization and adaptation. We have found that the interaction of universal processes and the natural change of cycles stimulates, on the one hand, growth and stabilization, and, on the other, - transformation and metamorphosis, which lead to the emergence of new forms and structures of public spaces and penitentiary complexes. We have proposed to use Socionical methods for increasing tolerance and democracy in the architectural environment of settlements. We have described the methodological tools to achieve the harmonization of the architectural environment of settlements.
\end{abstract}

\section{Introduction}

Sustainable development problems, which have become especially relevant and highlighted in international documents, have gradually gained a proper place in architecture and urban planning $[1,2]$. The global nature of these problems required large-scale methodological tools for their positive solution. A synergistic approach is one of them. It aims at tolerant Socionic cooperation and self-organization of all participants of the urban environment sustainable development. It involves the study of complex systems, the development of which has signs of sustainability and dynamism.

Sustainable development of architectural and urban planning systems is subject to self-organization laws. They operate in a wide range and determine the formation of diametrically opposite types of architectural environment - socializing (public spaces) and resocializing (penitentiary complexes).

Some scientists have studied the problems of urban self-organization. New areas of research - Urban Synergetics and Architectural Socionics have formed on this basis. The relationship between self-organization and the sustainable development of public spaces and penitentiary complexes, taking into account social relations, has not yet been considered. The solution to these problems is of paramount importance in modern architectural and urban planning theory. The expected results are important for Ukraine, where reforms in urban planning, medicine, education, and other spheres of life continue [3,4]. New explorations of the features of sustainable development, self-organization and interpersonal relations in urban public spaces, and penitentiary complexes are a direct continuation of our previous research on this topic [5].

Modern cities occupy huge territories and unite various population groups, the interaction between which quite often has polarized and extreme character. This character, on the one hand, testifies to the stability and, on the other, to the dynamism of the urban environment and, in total, determines the boundaries and range of settlements sustainable development. The public spaces are the most actively developing therein that maximally socialize the lives of urban residents. The urban environments of correctional facilities, which aimed at convicts re-socializing and preparing them for regular free life, oppose them. The urgency of the problem lies in the awareness of the need to close the gap between mutually polarized lifestyles.

We need to find ways to organize and self-organize different groups of the population. Then people with different value systems will be able to support each other in a tolerant urban environment. Revealing cyclical order in the historical development of opposite types of architectural environments is the next task. It is associated with the elucidation of differences and similarities in the processes of their self-organization and sustainable development.

\footnotetext{
* Corresponding author: shebek.nm@knuba.edu.ua
} 


\section{Sustainable development ranges of the cities architectural environment}

\subsection{Features of self-organization of the correctional system and urban penitentiary complexes}

The architectural environment of the correctional system requires the introduction of sustainable development ideas. Specialists in various fields of knowledge (criminologists, psychologists, sociologists, architects, and designers) are concerned with the problem of the architectural environments' creation, where humanity, justice, and order are harmoniously coordinated and balanced.

Trends in the development of scientific knowledge over the past 30 years provide an opportunity to say confidently that today synergetic concepts are spreading in many areas of scientific, theoretical, and applied activities. The synergetic approach allows us to consider the problems of the penitentiary system development and the architectural environment of correctional facilities from new positions. It provides new opportunities for its harmonious development, improvement, and sustainability.

D. K. Corten has described the conditions for sustainable development of social institutions [6]. Among them is a guarantee of safety and conditions for selfimprovement. Penitentiary complexes belong to such institutions. A harmoniously developing dynamic system must maintain a stable mode of operation, despite external interference [7]. Environmental, economic, and social components determine the sustainability of the systems. The system can develop differently in each of these areas. Social systems are less stable than, for example, ecological and biological. Prison riots and rising suicide cases are among the crisis indicators inherent in penitentiaries.

Opposing trends in the development of systems arise due to internal contradictions and external intervention. They can lead to either the destruction of the system or its improvement. O. M. Knyazeva and S. P. Kurdyumov believes that all existing systems are open, that is, have an exchange of energy and information with the environment [8].

We propose to consider the historical development of the penitentiary system from a synergistic standpoint. The cycle of its development begins from the phase of the punishment and detention conceptions emergence and accumulation in correctional facilities. The system is in a state of dispersion. From the chaotic conceptions of punishment, new individual forms of institutions emerge, such as the Zuchthaus in Amsterdam (1595), the prison for beggars in Britain (1563), and the prison for young men of St. Michael in Rome (1735) (Fig. 1).

At the next stage, the approaches to the legal framework formation change. Views on the problem of criminals correcting transform too. Realistic and utopian conceptions of correctional facilities emerge and strengthen their positions. Among them - the penitentiary in Philadelphia (1776), the Panopticon (1791), the Auburn
Detention System (1820), and the Irish Progressive System (1850). Selection of optimal technological and spatial solutions of correctional institutions takes place. The most "progressive» options for retention and correction are becoming more common. At this stage, the self-organization processes of the system are occurring.

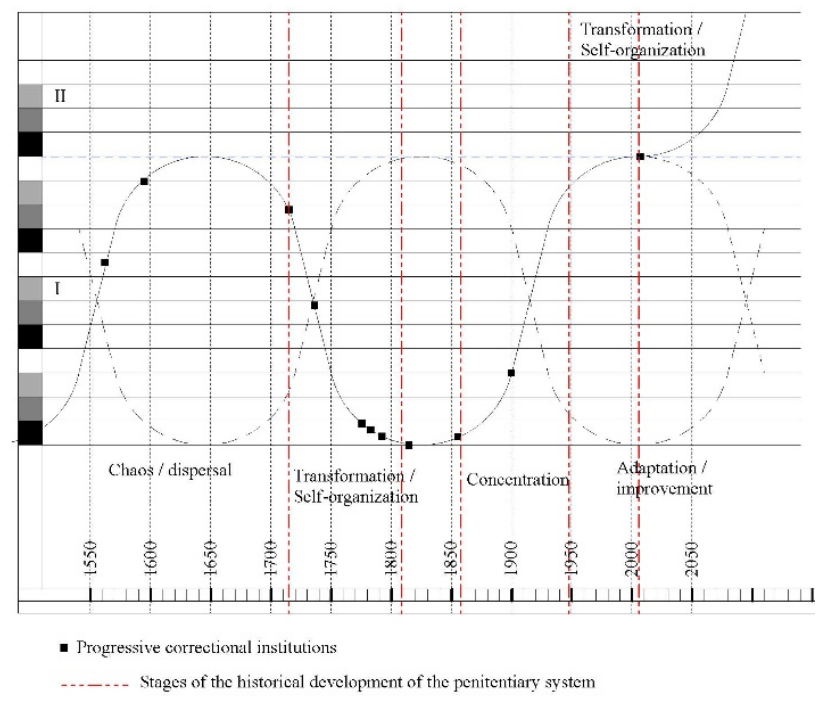

Fig. 1. Scheme of cyclic development of the penitentiary system environment, by Yuliia Tretiak.

Following this, the punishment system is stabilizing. At the stage of concentration, it changes due to the detection of shortcomings. At the same time, awareness of the possibility of returning to past concepts arises. These are the so-called negative feedback loops. For example, the progressive step system of detention of prisoners of the second half of the 19th century acquired the features that operated in the prison of St. Michael in Rome, which functioned since 1735.

For the next almost 100 years, the correctional system was in a stable cumulative state. The Declaration of Human Rights, adopted in 1948, once again changed the socio-humanistic emphasis in the prison sector.

The final phase of the system development cycle is an adaptive one. The results of knowledge accumulation integrate into the paradigm of system modernization at the next hierarchical level. The first period took place in the 1960s and 1970s when the "new wave" penitentiaries appeared in Europe. The second wave followed the prison riots of the 1990s when European countries set out to humanize the correctional environment.

Completely new forms of punishment have rarely emerged in the history of the penitentiary system. The reasons for such system stability were the minimal influence of external factors. The rigid nature of the legislative and regime component of the punishment system restrained this external influence. Thus, the processes of self-organization and adaptation in "closed" systems (prisons, military and labor camps, and towns, psychiatric hospitals) cannot take place fully. Regime restrictions in space and time deprive the process of development of the penitentiary system of extreme conditions. Therefore, completely new forms architectural complexes and buildings that have no 
analogs, occur very rarely.

The general cycle of the historical development of the correctional system lasts 120-150 years. Similar processes occur at the level of individual buildings and structures complexes. The life cycle of the building complex of the famous Strangeway prison in Great Britain demonstrates the historical development of its architectural and urban environment for more than 150 years.

A prison for 1,000 men and women opened in 1868 in the park. The plan of the building has the form of a "star" with ten rays. The method of detention and correction in the institution took into account the progressive (Irish) system. The period of "self-organization" of the environment took place until 1963. The transformation into a men's prison took place in 1948 under the influence of the Declaration of Human Rights. From 1964 to 1990, Strangeway experienced a phase of "concentration" when it returned to a harsher detention regime that did not comply with updated and more humane laws.

In April 1990, a series of riots broke out in Strangeway Prison. Damage to the building was one of the reasons for the reconstruction and modernization of the complex. During this adaptive period, the transition to a higher level did not take place in this institution. Reconstruction of the correctional complex could lead to the emergence of new forms. A full-fledged open space could enter the structure of the building. However, the reconstruction of $1994 \mathrm{did}$ not fulfill the corresponding task (Fig. 2). The system returned to the previous stage. To date, regular violations of the detention regime occur in the institution. In 2017, the Independent Oversight Board concluded that Manchester Prison is in urgent need of modernization.

The historical development of penitentiary institutions has shown the pivotal moments of the penitentiary system transformation. It also creates conditions for a rethinking of alternatives.

Synergistic research in economics, sociology, and demography suggests a gradual decline in crime. There are not only objective external but also internal reasons for this. The economic crisis and the stabilization of the population in developed countries are external causes. Tolerance, humanism, and the introduction of alternative means of punishment are internal reasons.

Today, the architectural environment of penitentiary complexes is in a crisis, precarious state. According to the ideas of synergetics, such instability can be a condition for further stabilization and dynamic development of the penitentiary system.

\subsection{Architectural Socionics and humanization of the environment of correctional complexes}

One of the many possible understandings of the philosophical dilemma of good and evil determines the construction of the penitentiary system in various countries. Each society at each stage of its development chooses the most acceptable ways to achieve a balance between good and evil and appropriate approaches to combating crime. The specific solution to this problem determines the purpose of forcible detention of people who have broken the law.
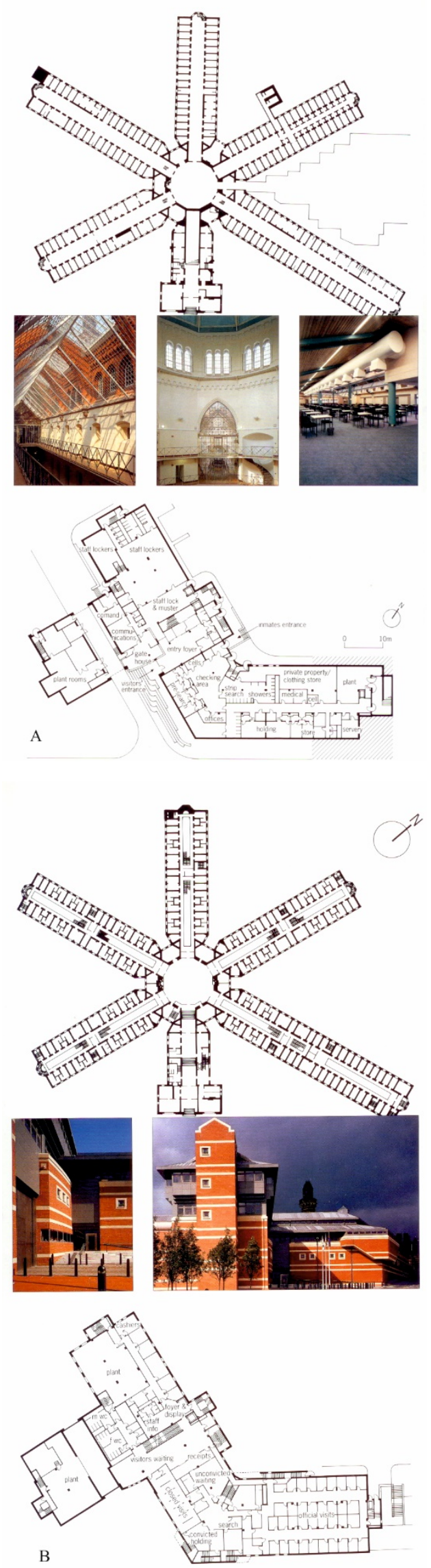

Fig. 2. Strangeway Prison before (A) and after (B) reconstruction. Plan of the building for prisoners (top) and plan of the administrative building (bottom) [9]. 
Therefore, different penitentiaries solve different and, in essence, opposite problems. Some of them focus on punishing criminals and making it impossible for them to commit atrocities for a certain period. Others try to reeducate people who have committed some offenses for one reason or another.

The architectural environment of detention places is subject to the primary purpose of freedom restricting of these people. Nowadays, therefore, there are prisons with a polar attitude to detainees in different developed countries. Conditions of stay in some of them are intolerable, and in others - similar to sanatoriums. For example, Japan's prison conditions are very harsh (Fig. 3) [10]. Instead, new prisons in Denmark or Norway impress with their humane treatment of detainees (Fig. 4) [11].

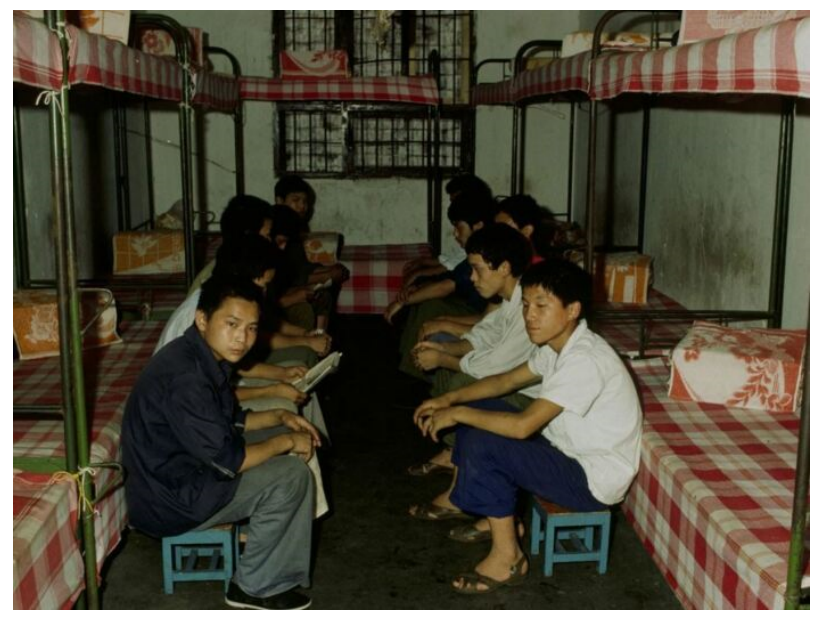

Fig. 2. Prohibition of communication even between convicts, Japan, https://novate.ru/blogs/140920/56010/.

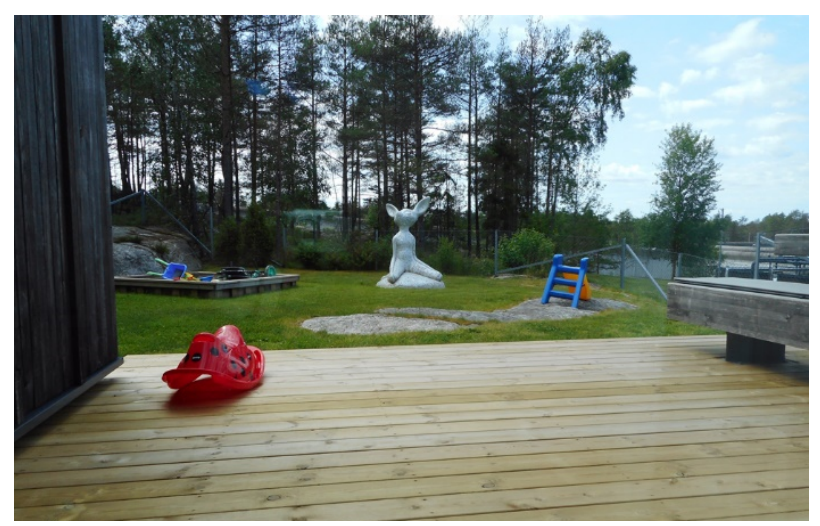

Fig. 3. The little play garden for communication of convicts with families in Halden Correctional Facility, Norway https://www.bbc.com/news/stories-48885846

Ironically, both situations do not contradict elementary logic. The first approach appeals to the instinct of self-preservation because the strict order should arouse the desire never to return to prison. In this case, fear should deter criminals from re-offending. The second approach appeals to everyone's innate desire to be better than he is now. The support a person receives during imprisonment will help them achieve what they want. As a result, the former convict will not return deliberately to the wrong path.
Naturally, the question arises - if there are no violations of logic in both cases, why none of both approaches can solve the problem of crime finally. Likely, the matter is not in the architectural and planning solution of the detention places and not in the rules of organizing this process. It may be wrong to use inappropriate methods of influencing different types of people. We believe that a unified attitude towards people is the root cause of many problems occurring in various spheres of social relations. In particular, severe punishment will oppress one person and anger another, encourage one to be cautious, and strengthen the desire for revenge in another. Similarly, the humane treatment of one detainee will encourage spiritual growth, and of the other will allow self-improvement in the criminal craft.

In our opinion, an attentive attitude to each psychological type will significantly alleviate the crime problem, if not solve it. In this way, architects aim at creating the most diverse physical and spatial conditions in buildings and complexes designed for imprisonment. However, it would be good that specialists in Psychology and Socionics work in the penitentiary system. They would be able to determine the type of energyinformational metabolism of each person, committed the offense. Positive experience to the application of Socionics in Pedagogy, Psychology, Business, Politics, artificial intelligence technologies development, and the intelligent systems' formation confirms this hypothesis [12].

Understanding the values system of the appropriate psychological type would allow choosing the optimal detention conditions, both for those who can re-educate and those who have made a life choice quite consciously and are not going to change it. Socionics specialists would provide an invaluable service to convicts if they were involved in the micro collectives formation in correctional institutions. After all, the compelled longterm stay of people with opposite value systems in the same room causes unnecessary suffering to all participants in such relationships and in no way contributes to the re-education process.

Based on the development of architectural Socionics [13], we propose to supplement the architectural typology of penitentiary institutions by allocating within it at least four types of correctional buildings and complexes. The penitentiary institutions' architectural environment of each proposed types should take into account the value priorities of the relevant Socionic quadra, in other words, - a category of people with a similar worldview, whose psychological types complement each other in pairs. This step will allow architects to offer optimal architectural and planning solutions for correctional buildings and complexes of four types. The first type is for the temporary detention of persons with extraordinary creative abilities (quadra $\alpha$ ). The second type is for the temporary detention of persons who support centralized, hierarchical systems, which respect the authorities, focused, primarily, on the strength (quadra $\beta$ ). The third type is for convicts seeking personal self-realization (quadra $\gamma$ ). The fourth type is for individuals who are willing to work on personal self-improvement (quadra $\delta$ ). 
The distribution of offenders in correctional facilities, which architectural environment will correspond to the detainees' psychological types, will not only improve their fate but also create the conditions for the time spent behind bars not to turn into years erased from their lives. On the other hand, such an organization of correctional facilities will facilitate the work of penitentiary staff, increase the effectiveness of the impact on the consciousness of detainees, will improve society's attitude to the penitentiary system. The practical implementation of our proposals, ultimately, will lead to the achievement of a synergistic effect - to the humanization of the penitentiary system as a whole.

\subsection{The ways to update the open public spaces of the city}

Compared to other fragments of the urban environment, public spaces are more sensitive to settlements' transformations. The natural (undistorted) transformation process of urban centers corresponds to the laws of the evolution of complex open, nonlinear systems. It involves the consistent stages of repetition of dispersion, selforganization, concentration, and adaptation.

At the stages of dispersion, various forms of social activity spontaneously occupy new territories. In the phases of self-organization, the selection of the most acceptable ways of interaction between residents takes place. At the stages of concentration, the number of public functions in the respective urban areas increases, and the structural elements of public spaces become more complicated. The use of material and human resources is increasing. Due to this, the territory of public spaces expand, buildings rebuilt, landscaping is improving. During periods of adaptation, community centers are experiencing a stage of prosperity. At this time, the architectural environment of public spaces reaches its maximum diversity. It becomes able to meet the expectations of different categories of the population. Circumstances, most favorable for the transition of public spaces to a qualitatively new structural development level, are forming in such historical periods. If cities fail to make the necessary efforts at the right time, the quality of public life in their centers declines. The oscillating processes of their transformation continue in a monotonous rhythm in anticipation of the next possibility of an evolutionary leap.

A short digression into the development history of the main square of Ukraine capital allows us to illustrate this process with concrete examples. For centuries, the territory of the modern main square of Kyiv has played a leading role in the development of the city. In the 11-13th centuries, one of the main entrances to the Old Town was there. Public life was bustling in this place. However, in 1240 Kyiv fell under the pressure of the invaders. Any activity in the city froze for almost four centuries. The harmonious development of the settlement was interrupted.

From the 17th century, Kyiv began to return to life. The city gates on the road from the Old City to Pechersk resumed work. The water mill began to operate here. Later, the first residential buildings appeared in this area.
Since the 19th century, public space began to function here. Pubs and taverns, dens, and brothels actively received visitors. Until 1818, the detention center functioned next to them. That is, the concentration of functions took place in public space.

In the middle of the century, on weekends, the then Khreshchatyk square performed trade, show, and recreational functions (Fig. 5). In 1843, the first fountain appeared in the square, but, at that time, it mainly satisfied economic needs. The public space was actively operating. Thus, this period testifies to the adaptation of the urban environment to the urgent needs of residents.

Over time, stone houses began to displace wooden houses from the square. In the mid-1850s, paving stones first covered the roadway. In 1866, the first public library began to operate on Khreshchatyk Square. The latest technologies had their origin here. For example, in 1864, the first kerosene lanterns appeared here. In 1872, gas lanterns replaced them [14].

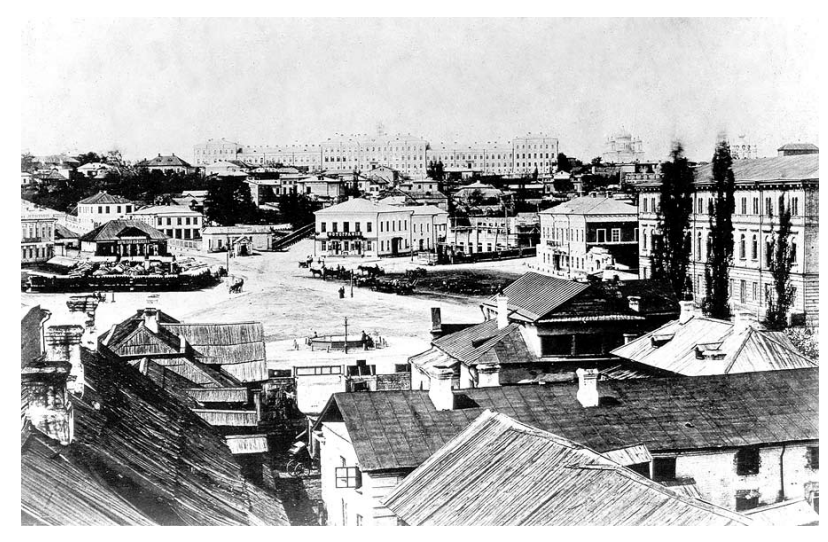

Fig. 5. Panorama of Khreshchatyk Square. Photo of the 1860s, http://archunion.format.com.ua/history/history_004_01.shtml

In 1878 , the building of the City Duma appeared on the square. This area has become the administrative center of the city. In 1892, the first trams crossed the then Duma Square. The accumulation of resources to improve the consumer quality of public spaces has reached its maximum at the stage of self-organization.

In 1909, a cozy square with an iron fountain appeared here (Fig. 6). New functions appeared here at the concentration stage - recreation, communication, political meetings, and celebrations.

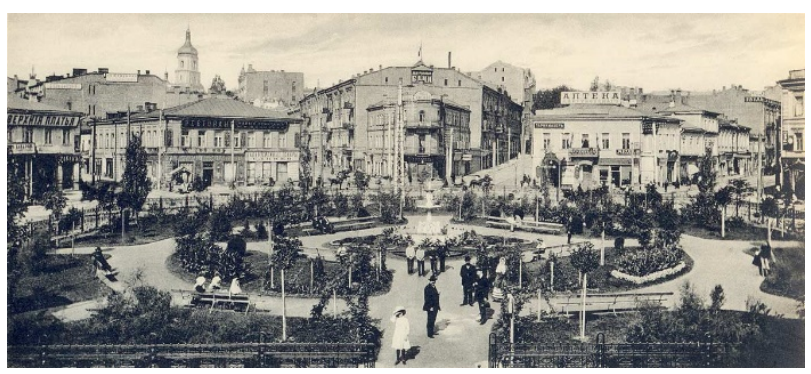

Fig. 5. Duma Square. Photo of the 1910s, http://archunion.format.com.ua/history/history_004_02.shtml

At the next stage of adaptation, the Second World War interrupted the sustainable development of the main 
square of Kyiv. The historic buildings there have almost completely disappeared.

In the third quarter of the twentieth century, a new cycle of the historical development of the central square of the city began with the stage of concentration of functions in the public space. The new buildings have replaced their predecessors. The square with a fountain continued its operation. In 1946, the Christmas tree began to decorate the then Kalinin Square for the New Year holidays. The entertainment function has returned to the public space.

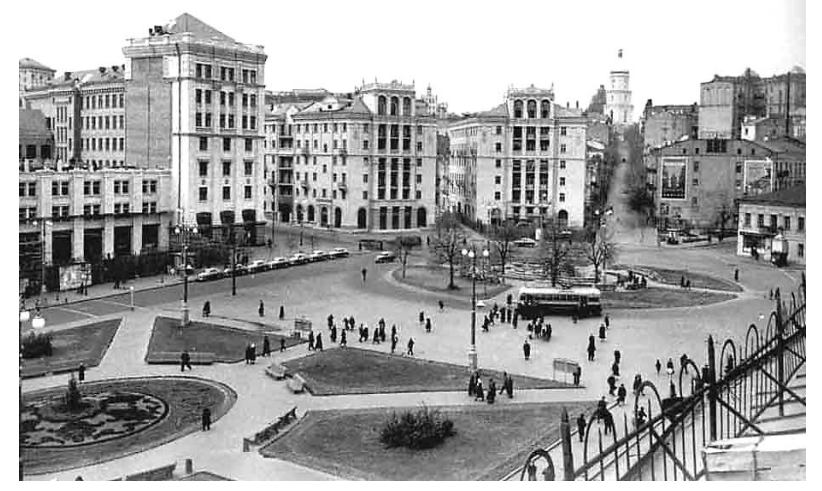

Fig. 6. Kalinin Square. Photo 1954,

http://archunion.format.com.ua/history/history_004_04.shtml

In 1964, the first underpass in Kyiv connected two parts of the square, separated by Khreschatyk Street. In addition to the ground, there was an underground level in the central public space. At the beginning of its existence, it provided the transit of pedestrian flows. However, as early as the 1970s, artists and street musicians began to use this space. Authorities struggled with this phenomenon, but not very successfully.

The "finest hour" of the city center began during the last quarter of the 20th century. In 1976, the subway station opened. In 1981, the main square of Ukraine underwent a large-scale reconstruction. Its open space has become more comfortable and grand (Fig. 7). People started spending much more time there. They gladly took part in numerous mass events, when the square turned into a dance floor or a concert hall. Children's holidays and folk festivals raged on the square. A large of events in the personal life of many city residents took place in this space.

A small museum appeared in the underground space below the western part of the square after the reconstruction in 1981. Visitors could see here the original remains of the foundations of the ancient Russian Lyadsky Gate. Anyone could visit this exhibition space at any time. The underground passage under Khreshchatyk Street at that time turned into a real public space, which was popularly called «Trumpet». There, artists demonstrated their skills, representatives of different subcultures met, restaurants, and shops worked [16].

The independence of Ukraine also affected the functioning of Kyiv's main square. It changed its name in honor of this event and became the main square of the country. The external push has moved the central public space of Maydan Nezalezhnosti to a qualitatively new round of urban evolution.

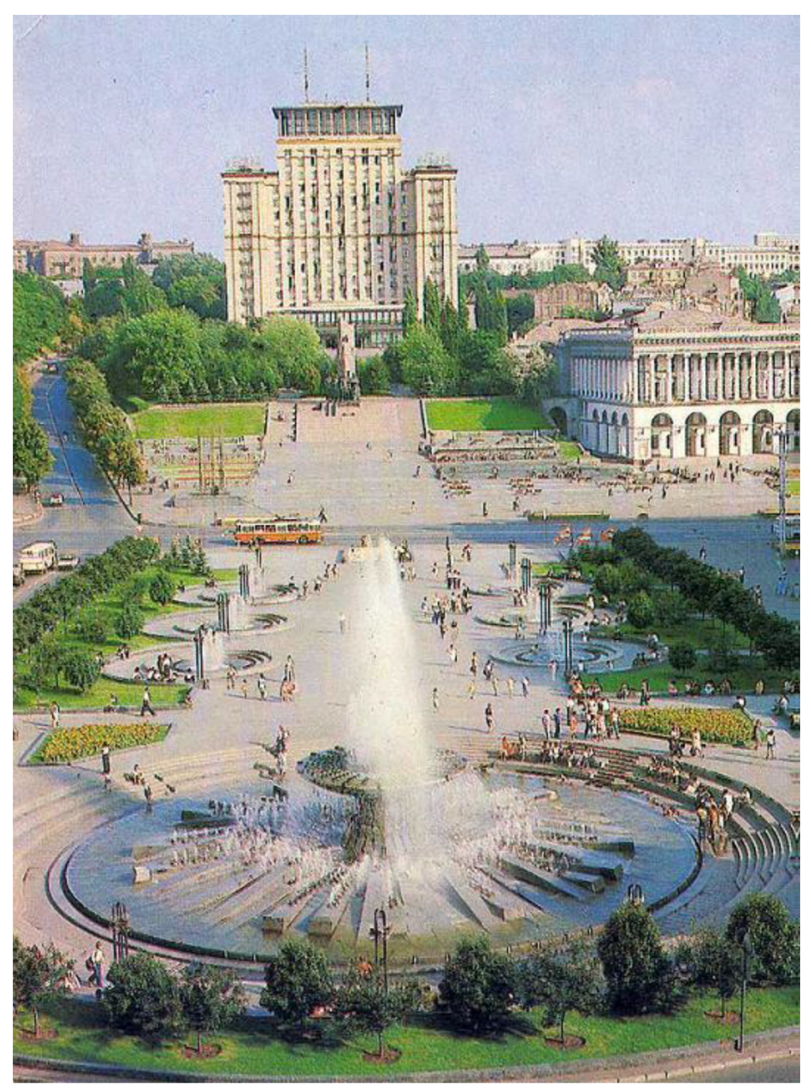

Fig. 7. October Revolution Square. Photo 1985,

http://infoportal.kiev.ua/ploshhad-nezavisimosti-v-kievenovaya-istoriya-proisxodit-zdes/

The next stage of concentration of public functions has begun in this territory. Reconstruction in 2001 radically changed the area. The underground museum, aboveground recreation areas, and a large fountain have disappeared. Instead, the "Globus" shopping and entertainment complex went under ground level on several floors and rose above its surface (Figs. 8, 9). The main open areas for communication and recreation are at ground level and above ground - in the park near the October Palace and the roof of the third line of the "Globus". The premises of the shopping and entertainment complex are becoming more popular in the cold season.

Already in the early 1990s, the main square of Kyiv became the primary place of public expression. In 1990, students who made demands to the government lived for a time in a tent camp in the city center. In 2004 and 2013, Independence Square became an arena for political struggle. In 2014, tragic events unfolded there, taking many lives.

The central square of the capital is gradually "healing" the wounds received during the Revolution of Dignity. However, this space will never be the same as before. A memorial was added to the list of his public functions. However, life goes on. A large-scale reconstruction of the underground passage near Khreshchatyk is underway.

The described events testify to the cyclical development of the central public space of Kyiv (Fig. 10). 
In this case, the stages of dispersal, self-organization, concentration, and adaptation successively replace one another. Trends in the historical transformations of this space coincide with ideas about the cyclical nature of sustainable development. This opens up prospects for predicting the ways of sustainable and dynamic transformation of public space in the center of Kyiv. They last for about 25 years, which corresponds to the duration of urban activity of one generation.

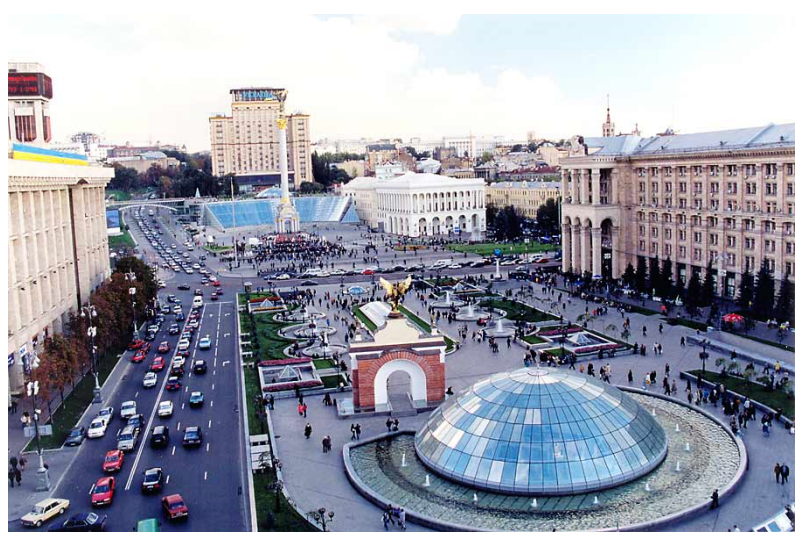

Fig. 8. Maydan Nezalezhnosti. Foto 2004, http://archunion.format.com.ua/history/history_004_12.shtml

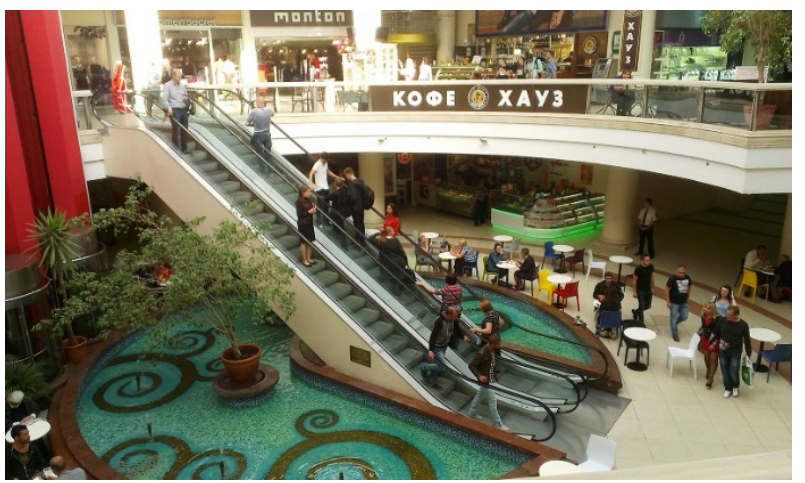

Fig. 9. Shopping and entertainment complex «Globus», http://abcnews.com.ua/ru/markets/pod-svodami-globusafotorieportazh

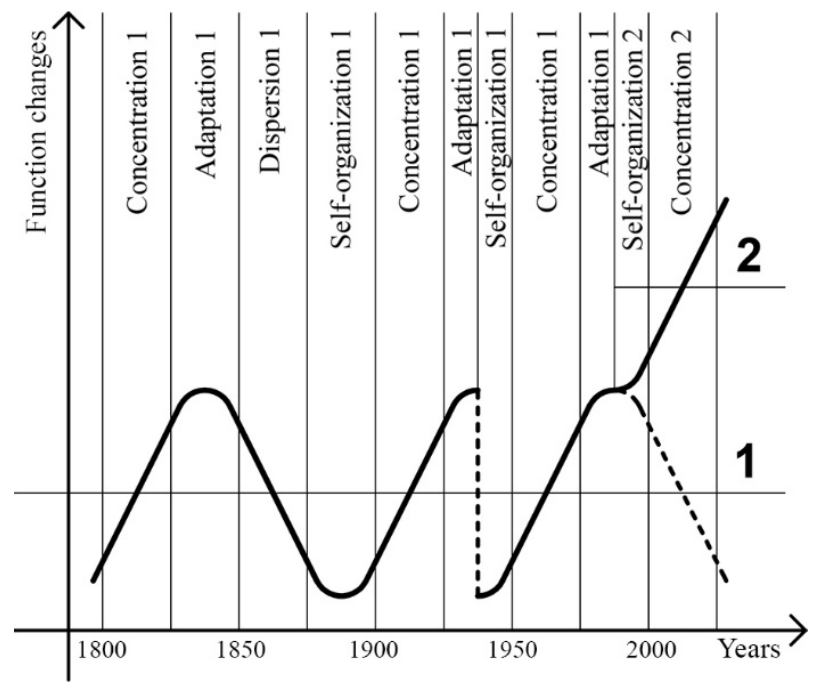

Fig. 10. Dynamics of historical development of the central public space of Kyiv: 1,2-levels of qualitative transformations, by Viktor Timokhin and Nadiia Shebek.

\section{Conclusions}

The search for new approaches to solving current problems of sustainable development of cities becomes especially important in the current conditions of reforming the architectural and urban planning industry in Ukraine. We found two opposite trends in sustainable development - the desire for stability and dynamism, rigidity of organization and flexibility of selforganization, tolerance, and hostility. Their mutual coordination is a reliable methodological basis for achieving the goal and solving sustainable development problems. We found that the dynamic component of constancy has a regular cyclical nature that manifested in a kind of genetic code of the alternation of pairwise polarized processes of dispersion and concentration, selforganization, and adaptation. On this basis, we have developed a new method of polarized cyclicity, which differs from existing methods in its dialectical content. It allows identifying important moments when minimal efforts stimulate a new round of sustainable development processes.

Their composition and order of deployment have signs of universality and are distinctive for all types of architectural environments in the city. Therefore, we used Synergetic and Socionic approaches to address sustainable development. Its cyclical nature is in the historical transformations of mutually polarized components of the city - the socializing public space and the resocializing environment of penitentiary complexes. Their diametric opposite outlines the range of tasks for diagnosing the stages of sustainable development and allows them to involve in their solving Socionic methods that contribute to the urban environment humanization.

The revealed patterns of historical and sustainable development and the usage of synergetic and Socionic approaches open new perspectives in architectural studies of transformations and metamorphoses of public spaces and the penitentiary environment. The list of methodological tools includes diagnosing these complex environments, finding out the reasons for their arrhythmic development, coordinating the phases of transformation, and efforts to maintain trends of sustainability and dynamism. They will contribute to achieving the goals, solving the problems of sustainable development of cities, and the humanization of the architectural environment of their various parts.

We propose to use this methodological approach in the architectural and urban planning practice to solve some problems. Among them: tasks of detailed planning of the territory, forecasting the stages of reconstruction and renovation of public spaces, penitentiary complexes, and other types of the urban environment.

\section{References}

1. Transforming our World: the 2030 Agenda for Sustainable Development, A/RES/70/1. (United Nations, New York, 25-27 September 2015), https://sustainabledevelopment.un.org/content/docu ments/21252030\%20Agenda\%20for\%20Sustainable 
\%20Development\%20web.pdf. Accessed 10 Dec 2020

2. RIBA Sustainable Outcomes Guide. (2019), https://www.architecture.com/-

/media/GatherContent/Test-resourcespage/Additional-

Documents/RIBASustainableOutcomesGuide2019p df.pdf. Accessed 10 Dec 2020

3. I. Bulakh, L. Kozakova, M. Didichenko, O. Chala, Sustainable futures in the context of architectural design of hospitals. E3S Web of Conferences 166, 08001 (2020), doi:10.1051/e3sconf/202016608001

4. G. Kovalska, I. Merylova, I. Bulakh, Urban improvement of comprehensive schools and out of school educational establishments in Ukraine. International Journal of Innovative Technology and Exploring Engineering 8, 12, 1765-1770 (2019). doi:10.35940/ijitee.L3229.1081219

5. N. Shebek, V. Timokhin, Y. Tretiak, I. Kolmakov, O. Olkhovets, Sustainable development and harmonization of the architectural environment of cities. E3S Web of Conferences 166, 09001 (2020)

6. D. C. Korten, Ustojchivoe razvitie: Obshcheprinyatyj stereotip i al'ternativnyj vzglyad (Sustainable Development: Generally Accepted Stereotype and Alternative View). http://civilg8.ru/6829.php (2003). Accessed 1 Dec 2020

7. N. V. Chepurnyh, A. L. Novoselov Ekonomika $i$ ekologiya: razvitie, katastrofy (Economy and ecology: development, disasters) (Nauka, Moscow, 1996)

8. Y. N. Knyazeva, S. P. Kurdyumov, Zakony evolyucii $i$ samoorganizacii slozhny sistem (The laws of evolution and self-organization of complex systems) (Nauka, Moscow, 1994)

9. I. Spens (ed.), Architecture of Incarceretion (Academy editions, London, 1994)

10. Why Japan's prisons are considered one of the harshest in the world when order and discipline reign there. https://novate.ru/blogs/140920/56010/ (Internet project Novate.Ru, 14 September 2020). Accessed 6 Dec 2020

11. How Norway turns criminals into good neighbours, BBC News Services, 6 July 2019, https://www.bbc.com/news/stories-48885846.

Accessed 6 Dec 2020

12. A. V. Bukalov, Sotsionika: gumanitarnyye, sotsial'nyye, politicheskiye i informatsionnyye intellektual'nyye tekhnologii XXI veka (Socionics: humanitarian, social, political and information intellectual technologies of the XXI century). Socionics, Mentology and Personality Psychology 1, (2000), http://socionic.info/en/et/2000eng.html\#top. Accessed 6 Dec 2020

13. A. Augustinavichute, Socion (Chernaya belka, Moscow, 2008)
14. A. V. Voznyts'kyy, Maydan Nezalezhnosti (Ploshchad' Nezavisimosti) (Independence Square) http://archunion.format.com.ua/history/history_004_ 01.shtml. Accessed 15 Dec 2020

15. A. V. Kudryts'kyy (ed.), Vulytsi Kyyeva (Streets of Kyiv) (Ukrayins'ka entsyklopediya im. M. P. Bazhana, Kyyiv, 1995)

16. V. Snacheva, Ran'she v "trube" na Maydane vstrechalis' rokery, a teper' priyezzhiye ishchut vykhod na Kreshchatik (Earlier rockers met in the "pipe" on the Maidan, and now visitors are looking for an exit to Khreshchatyk) (Segodnya, 15.03.2013) https://kiev.segodnya.ua/kiev/kpower/Ranshe-vtrube-na-Maydane-vstrechalis-rokery-a-teperpriezzhie-ishchut-vyhod-na-Kreshchatik424441.html. Accessed 15 Dec 2020 